\title{
The Analysis of Workload and Work Environment on Nurse Performance with Job Stress as Mediation Variable
}

\author{
Yosiana*, Adya Hermawati and Muchlis H. Mas'ud \\ ${ }^{1}$ Department of Management, Postgraduate Program, Widyagama University of Malang, Indonesia
}

(Received April 16, 2020; Accepted April 28, 2020; Published May 12, 2020)

\begin{abstract}
Nurses have a vital position in providing health services in the community in district areas. Their work situation needs to be considered in order to provide optimal service. This study aims to analyze the effect of workload and work environment on nurse performance and study work stress as a mediating variable on nurse performance. This research was carried out by using the survey approach to nurses working in Puskesmas in Tumpang district working area. Path analysis was applied to obtain the relationship between the variables studied. The results show that if high works are handled by a small number of human resources, it will only result in high workloads and then increase work stress. A conducive work environment not only helps nurses to control stress but also allows them to improve their performance.
\end{abstract}

Keywords: job stress, nurse, puskesmas, workload, work environment, Malang

JEL Classification: I18, J24, M54

\section{INTRODUCTION}

Community health center (Puskesmas) is technical implementing units that are responsible for carrying out tasks to provide health care services in a district work area in Indonesia. Puskesmas provides health services to meet the needs of inpatients, outpatients or polyclinics, and intensive care units. Medical personnel, especially nurses, have an essential role in providing health care services, where they interact directly with patients and serve their various needs. Nurses are at the forefront of health care services, especially in Puskesmas, where their ability as medical personnel is vital for determining the quality of health services to the community.

Measuring the workload of nurses is an urgent matter to learn because they are the key to health care. The size of the nurse's workload relates to the number of patients and the state of available health

\footnotetext{
* Corresponding author email: etainamama@gmail.com ISSN 2615-6075 online; ISSN 2615-6946 print @UWG Press, 2020

OJS http://publishing-widyagama.ac.id/ejournalv2/index.php/jsed/
}

facilities (Ulrich, Barden, Cassidy, \& Varn-Davis, 2019). This will also relate to the performance of nurses, whether they can serve patients satisfactorily or otherwise display negative services (Aiken et al., 2018). Performance is the level of achievement of a person in a certain period after the task is completed based on predetermined indicators, including work standards and work targets (Rivai, 2009). In many cases, it can be understood that complaints will arise about the services provided by nurses (Aiken et al., 2018).

The data show that the average workload of nurses shows a significant increase. In the period 2016 to 2018, nurses' performance scores tended to increase, namely 7.2 (2016), 7.54 (2017) and 7.38 (2018), respectively. This results in increased work pressure among nurses in carrying out tasks. In the same period, the Bed Occupancy Rate (BOR) indicator also increased, namely 65.1, 81.3 and $90.2 \%$, respectively. The ideal value of BOR ranges from $85 \%$ to $75 \%$ (Sudra, 2014). This was also followed by an increase in patients from 1,543 people in 2016 and then increased to 1,723 people and 1982 in the next two years. This situation can 
result in a heavy workload for the nursing team, and nurses cannot carry out standard operating procedures for medical services properly. This can lead to the risk of mismanagement, decreased quality of work, possible risk of nosocomial infection, and decreased level of cleanliness of Puskesmas medical facilities and infrastructure. A favorable nurse work environment is the cornerstone to the sustainable nursing workforce and positive outcomes for contributing role in health care services (Paguio \& Yu, 2020).

Job stress is a consequence of a high workload and it happens because an optimal work environment is not supported. The work environment needs to be properly managed so that it can prevent stressful conditions and encourage high performance. Robbins \& Judge (2017) defines work stress as an unfavorable psychological condition in response to pressure from the work environment. It said that work stress at a high level can cause performance to decrease significantly. Difayoga \& Yuniawan, (2015); Shabbir \& Naqvi, (2017); Wollah, Rompas, \& Kallo, (2017) have proven that work stress has a negative effect on performance. Instead, different things were reported by Indriyani (2009) and Van Den Hombergh et al. (2009) who found that work stress positively affects performance. Some companies experience that skilled stress management can make work motivated to have a good impact on performance.

The work environment can be a potential source of work stress. According to Robbins \& Judge (2017), the work environment is everything around workers that can affect the way they work and their productivity (Nitisemito, 1982). The work environment is an uncertain environment that affects the design and structure of the organization. This uncertainty is the strongest reason why many workers always have problems with changes in workplace organizations. Likewise, with conditions at the Puskesmas, limited health care facilities, and too many patients served, can potentially increase work stress among nurses. Hayes, Douglas, \& Bonner (2015); Rizki, Hamid, \& Mayowan (2016) show that the work environment has a negative effect on work stress.

According to Robbins \& Judge (2017), changes in workload can change the level of work stress, and these changes greatly affect employee performance. Ambarwati \& Lataruva (2014) have revealed that workload negatively affects nurses' work stress. However, according to Hannani, (2016) and Shabbir \& Naqvi (2017), workload positively affects work stress.

The results of formulas that involve workload, work environment, and work stress are performance. Under the statement delivered by Mangkunegara (2012), performance is the result of work achieved by employees in quantity and quality based on the specified plan. High employee performance will bring a positive effect on organizational performance. Conversely, low employee performance will have a negative impact on organizational health, or will only disadvantage the organization.

In 2018, Puskesmas in Tumpang showed lower performance compared to the previous period. This relates to the rules by The National Health Care Insurance (BPJS Kesehatan), which stipulates that all patients must start or refer their care (level-1 health facility) at the Puskesmas. Moreover, if the Puskesmas has inpatient services, the patients must be treated at the facility. Such an arrangement resulted in a significant increase in the number of inpatients, even exceeding the number of facilities and the ability of nurses. This is understandable, and it will increase the workload of the nurses.

Based on the conditions found related to the performance of nurses in Puskesmas Tumpang subdistrict, this study tries to explore deeper into the relationships between performance, workload, work environment, and work stress in nurses' work lives. This research is very relevant and therefore, it is sufficient to get an address on the issue of the performance of the nurses in Puskesmas in Tumpang district.

This study aims to analyze the relationship between workload, work environment, work stress and its effect on nurse performance, and to study work stress as a mediating variable on nurse performance.

\section{RESEARCH METHOD}

The study was carried out in the work area of the Puskesmas in Tumpang district, including 
Tumpang, Jabung, Pakis, and Poncokusumo. The study was conducted in 2019 and involved nurses who worked at these four Puskesmas. These Puskesmas were chosen because they have a similar character, which provides services to rural communities who are mostly Madurese and live in the valley of Mount Semeru and Mount Bromo.

The number of nurses in the work area of the Puskesmas in the Tumpang district was 113. All of them became the research respondents. Determinating the number of samples is essential for expecting accurate results to meet the research objectives.

The survey was conducted by distributing questionnaires to the nurses in the effort to explore the workload variables (X1), work environment $(X 2)$, work stress $(M)$, and nurse performance $(Y)$. Indicators of each variable were obtained by using Likert ordinal scale measurement through five categories of answers, namely, strongly agree, agree, disagree, disagree, and strongly disagree. Latent variables $X 1, X 2, M$, and $Y$, each consisted of $2,2,5$, and 4 indicators, respectively. Hypothetical relationships between latent variables are presented in Figure 1, which is formulated using the concepts already explained.

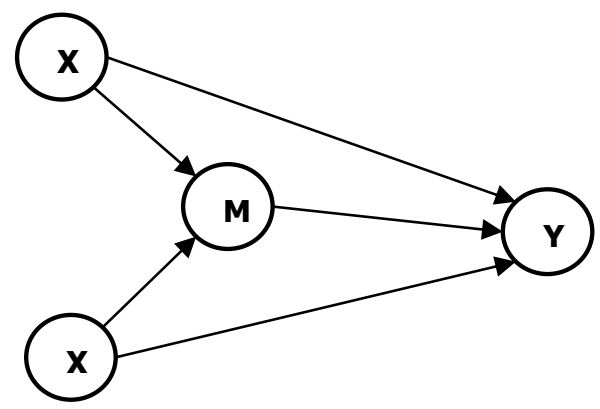

Figure 1. Hypothetical Model Framework of Variables

Path analysis was used as the data analysis method based on the framework model Figure 1. Path analysis uses a similar analytical approach with linear regression analysis; the difference is that path analysis involves standard observational values. Therefore, the path coefficient is basically like the beta coefficient in the linear regression model. Path analysis was operated using the Statistical Product and Service Solution (SPSS) software. It was also use to run the validity and reliability testing procedures, and to obtain robust models and estimates.

\section{RESULT AND DISCUSSION}

\section{Characteristics and Performance of the Respondents}

The descriptions of nurse respondents in the Puskesmas in Tumpang working area are presented in Table 1.

On average, the majority of respondents were female $(71.7 \%)$. They worked as a nurse with 6-10 years of experience $(21.2 \%)$. Most of them graduated from D3 in Nursing (92.9\%). 50.4\% of them were 30-40 years old. Their current occupational status was in the civil servant scheme, precisely at the position of the rural nurses (57.5\%).

Table 1. Characteristics of Respondents

\begin{tabular}{lc}
\hline Characteristics & Percentage \\
\hline & $\%$ \\
Gender (female) & 71.7 \\
Work experience (6-10 years) & 21.2 \\
Education (D3 in Nursing) & 92.9 \\
Age (30-40 years) & 50.4 \\
work status as rural nurse & 57.5 \\
\hline
\end{tabular}

Sample size $=113$

In general, nurses' profiles in the Puskesmas in Tumpang working area show that they had a high potential to carry out tasks in health care services at the Puskesmas. They demonstrated adequate educational qualifications at a relatively young age. Their employment status as public servant strengthened their position in the duty and responsibility legally. Their performance is expected to be able to provide services to the community. As such, Puskesmas care service was strongly associated with nursing care provided, which in turn was related to professional nurse and work environments. Improving nurse staffing in Puskesmas holds promise for enhancing patient satisfaction (Aiken et al., 2018).

Meanwhile, responses of nurses in terms of workload variables $(X 1)$, work environment $(X 2)$, job stress $(M)$, and nurse performance $(Y)$ are presented in Table 2. It basically reflects the behavior of nurses regarding the conditions and works environment or factors that affect its performance. The validity and reliability tests were 
also done in the results in Table. It shows that the items of variables were valid, and the research instrument was considered reliable.

Table 2. Mean Scores of Variables

\begin{tabular}{lcc}
\hline Variable & Mean & Criteria $^{\mathrm{a}}$ \\
\hline Workload $(\mathrm{X} 1)$ & 3.56 & High \\
Work environment $(\mathrm{x} 2)$ & 3.95 & High \\
Job stress $(\mathrm{m})$ & 2.52 & Low \\
Nurse performance $(\mathrm{y})$ & 4.04 & High \\
\hline${ }^{\mathrm{a}}$ Cronbach alpha value is over 0.6 &
\end{tabular}

The mean score of workloads among nurses at Puskesmas in Tumpang District was 3.56, and it is in a high category. This category indicates that nurses suffered workload at a high level, and they got many problems such as health instability, mental distraction, lack of resting, overnight shift, job overload, and too many tasks or jobs handled by one nurse.

The work environment of the nurses had mean score of 3.95 , which was categorized as high. This score signifies that the work environment of the nurses at Puskesmas in Tumpang District was good and favorable. It was proved by the presence of several conditions such as physical work environment that supports nursing job; the existence of air circulation that made the nurses more convenient at work; the feeling of secured at work; and good relationship that nurses have either with their superiors, coworkers, or subordinates.

Job stress among the nurses at Puskesmas in Tumpang district was in the low category, which is shown by a mean score of 2.52 . This low category indicates that the nurses were already successful in managing their own stress. Despite their high workload, they still could overcome internal conflict with coworkers and build good cooperation with other units. Good relationships with other individuals at Puskesmas had enabled the nurses to operate work instruments at good precision, especially when they must handle critical patients. Building intimate relationships with patients had allowed the nurses to receive information about the patient's conditions that a doctor might not know what about. In the case of death, the nurses could use their knowledge about the patient's condition to take the proper actions considered necessary for corpse handling.
In many cases, nurses probably provided equal or possibly even better quality of care compared to primary care doctors. It also perhaps achieved equal or better health outcomes for the patients. Compared to primary care doctors, nurses also often provided higher levels of patient satisfaction. Also, consultation length, care, and the frequency of attended return visits were definitely slightly higher for nurses, compared to doctors (Laurant et al., 2018).

The mean score of nurse performance is 4.04 , and it is in the high category. This category signifies that the nurses at Puskesmas in Tumpang District had been able to manage their job stress properly. They still bear a high workload, but they successfully suppressed the conflict potentially occurring against other individuals. As a consequence, they could do their main task and their integrated job in proper ways and then use their authority and responsibility optimally.

\section{Model Specification of Nurses' Performance}

The model between variables is as per the hypothetical relationship specification formulated in Figure 1. This model would prove the relationship between variables, whether fulfilling the feasibility to explain the phenomena of the relationships or the path between workload (X1), work Environment $(\mathrm{X} 2)$, job stress $(\mathrm{M})$, and nurse performance $(\mathrm{Y})$.

Initial tests were carried out to ensure that the model path was feasible to use. The test included the normality test with residual regression, multicollinearity test, and heteroscedasticity test. Overall testing results (shown in the Appendix) show that the model proved to be very robust and feasible to use to explain the relationship between the variables.

The model specifications of the relationships between the variables produce the phenomenon of direct relations and indirect relationships, as presented in Tables 3 and 4. As such, this also reflects the effect of a variable on other variables.

Table 3 shows that the workload has a positive and significant effect on job stress. Based on this result, it is confirmed that the workload at a high level can increase job stress. This result confirms the prior studies of Hannani (2016) and Shabbir \& 
Naqvi (2017), in which they found that workload positively influenced job stress.

Table 3. Direct Effect between Variable Relations

\begin{tabular}{cccc}
\hline Effect $^{\mathrm{a}}$ & Path Coefficient & t-value & $\mathrm{p}$-value \\
\cline { 1 - 3 } $\mathrm{X} 1 \rightarrow \mathrm{M}$ & 0.410 & 4.463 & 0.000 \\
$\mathrm{X} 2 \rightarrow \mathrm{M}$ & -0.361 & -3.935 & 0.000 \\
$\mathrm{X} 1 \rightarrow \mathrm{Y}$ & -0.251 & -2.471 & 0.015 \\
$\mathrm{X} 2 \rightarrow \mathrm{Y}$ & 0.261 & 2.622 & 0.010 \\
$\mathrm{M} \rightarrow \mathrm{Y}$ & -0.283 & -2.925 & 0.004 \\
\hline${ }^{\mathrm{a}} \mathrm{X} 1 \mathrm{H}$ & Workload, $\mathrm{X} 2$ = Work Environment, $\mathrm{M}=$ Job Stress, $\mathrm{Y}=$
\end{tabular}
Nurse Performance

The work environment also had a negative but significant effect on job stress. Given this result, it can be said that a pleasant work environment will reduce job stress. Empirical evidence regarding this result was given by Hayes et al. (2015) and Rizki et al. (2016). They also discovered that the work environment negatively influenced job stress.

Meanwhile, the direct effect of workload on nurse performance shows a negative and significant effect on the nurse performance. In regard to this result, it can be stated that workload at a high level may create low nurse performance. Likewise, the work environment shows a positive and significant effect on the nurse performance. Regarding this result, it can be explained that a good and favorable work environment is associated with better nurse performance. This result is in line with the findings reported by Difayoga \& Yuniawan (2015), Nieuwenhuijsen, Bruinvels, \& Frings-Dresen (2010), and Ulrich et al. (2019), where they found that work environment positively and significantly influenced performance.

The direct effect of job stress on nurse performance shows a negative and significant relationship. It can be said that high job stress may cause low nurse performance. On the contrary, if job stress decreases, then nurse performance gets improved. Some studies confirmed this result (Difayoga \& Yuniawan, 2015; Shabbir \& Naqvi, 2017; Wollah et al., 2017), where they discovered that job stress negatively influenced the performance.

Furthermore, the indirect effect of workload on nurse performance through the mediation of job stress was also tested. The result of the test indicated that this indirect effect was negative and significant (Table 4). It is consistent with Shabbir \& Naqvi (2017), who found that the indirect effect of workload on performance through the mediation of job stress was indeed negative and significant.

Furthermore, the indirect effect of the work environment on nurse performance through the mediation of job stress indicated a positive and significant relationship. Empirical pieces of evidence concerning this relationship were submitted by Shea, Pettit, \& De Cieri (2011) where the indirect effect of work environment on nurse performance through the mediation of job stress was found to be positive and significant.

Table 4. Indirect Effect between Variable Relations

\begin{tabular}{lccc}
\hline \multicolumn{1}{c}{ Effect $^{\mathrm{a}}$} & Path Coefficient & t-value & $\mathrm{p}$-value \\
\hline $\mathrm{X} 1 \rightarrow \mathrm{M}$ & 0.410 & 4.463 & 0.00 \\
$\mathrm{M} \rightarrow \mathrm{Y}$ & -0.283 & -2.925 & 0.00 \\
$\mathrm{X} 1 \rightarrow \mathrm{M} \rightarrow \mathrm{Y}$ & -0.116 & -2.451 & 0.016 \\
$\mathrm{X} 2 \rightarrow \mathrm{M}$ & -0.361 & -3.935 & 0.00 \\
$\mathrm{M} \rightarrow \mathrm{Y}$ & -0.283 & -2.925 & 0.00 \\
$\mathrm{X} 2 \rightarrow \mathrm{M} \rightarrow \mathrm{Y}$ & 0.102 & 2.352 & 0.002 \\
\hline
\end{tabular}

${ }^{\mathrm{a}} \mathrm{X} 1$ = Workload, $\mathrm{X} 2$ = Work Environment, $\mathrm{M}=$ Job Stress, $\mathrm{Y}=$ Nurse Performance

All the results have inference, meaning that each workload, work environment, and job stress had a strong effect on the nurse performance at Puskesmas in Tumpang District. However, the workload might still be problematic due to the limitation of the equipment and workers. Recently, the workload of the nurses sharply increased because the number of patients received by Puskesmas surged. It relates to the operation of The National Health Care Insurance (BPJS Kesehatan), which guarantees finance for all patient services. Such problems must be overcome by supplying additional equipment and workers to the Puskesmas. Moreover, the high level of workload could produce psychological anxiety, mental distraction, and fatigue (during the night shift).

The work environment had a strong influence on other variables. A problem related to the work environment was that some nurses may not have a harmonious relationship with coworkers.

Work stress greatly affected the mental health of the nurses, especially when they have to refer patients to other polyclinics or other support units. This process involved coordination, which was relatively burdensome to the nurse when contacting or serving other units. It is suggested 
that a one-door service should be provided to make the patient do the procedure more orderly.

Performance had a strong effect on the work of nurses. The problem was that some nurses still found difficulty in evaluating the basic activity in nursing. The problems were also found in communicating with small and medium enterprises in a rural area, in facilitating public participation, in taking responsibility for the nursing activity, and in providing health care service based on the standard operational procedures. Often, many nurses must do multiple jobs, and therefore, it could disturb their main task.

High work volume handled by few human resources would only cause a high workload, including physical and non-physical workloads. High workload could enhance job stress and might force the nurses to suffer psychological problems. Hypothesis test was conducted on the hypothesis that workload has a significant effect on job stress of the nurses. The score for this hypothesis was 0.410 . Therefore, the hypothesis was supported.

A good and favorable work environment could reduce job stress situations. When the nurses found that physical and non-physical environments at the workplace were good and favorable, they could be more motivated to manage their job stress properly. A good and favorable work environment buildt the feeling of secure at work and also facilitated the nurses to develop harmonious relationships either with their superiors, coworkers, or subordinates. The hypothesis that the work environment had a significant effect on job stress was tested, and the obtained score was -0.361 . Based on this score, the hypothesis was proved.

Nurses were often in a position overwhelmed by overloaded work stress when they had to refer many patients to other polyclinics or other support units. This activity reduced the nurse's performance very significantly. Hypothesis testing on the relationship of work stress to nursing performance was in a path coefficient of -0.283 . It indicates that the negative relationship between work stress and nurse performance was confirmed.

The high workload was associated with low nurse performance. In the situation of high workload, the nurses always suffered psychological problems, which badly affected their performance.
High and low workloads relate to the low and high nurse performances. Hypothesis test was carried out on the hypothesis that the workload had a significant effect on the nurse performance. The path coefficient was -0.251 , and therefore, the hypothesis was supported.

A good and favorable environment could produce better nurse performance. A convenient work environment would make nurses more motivated at work. They felt not only more secured at work but also were able to develop a harmonious relationship with either their superiors, coworkers, or subordinates. The hypothesis that the work environment had a significant effect on nurse performance was tested. The result is that this hypothesis was proved, as indicated by a path coefficient of 0.261 .

The indirect effect of workload on nurse performance through the mediation of job stress was examined with the hypothesis test. The obtained path coefficient was 0.253 , which was a bit higher compared to 0.251 belong to the path coefficient indirect effect relationship. A low level of workload is associated with a low level of performance, and a high level of job stress mediates this relationship.

The indirect effect of the work environment on nurse performance through the mediation of job stress brought a path coefficient of 0.355 . It was higher than the path coefficient of 0.261 for the direct effect. A better work environment would increase performance, but it only happened in the context of low job stress.

\section{Research Implication}

Nursing is a very complex and a constantly evolving profession. There are five core competencies taught in nursing education, consisting of providing patient-centered care, working in interdisciplinary teams, applying quality improvement, using evidence-based practice, and using informatics (Tuthill, 2009). Given that conditions, the work life faced by a nurse requires understanding and skills focusing on enhancing the nurse autonomy, leadership and management support, teamwork, and workload management (Paguio \& Yu, 2020). 
Works in the field of nursing are multiple and complicated health care services. Many nurses should not handle this high volume of nurse work because it will only add the nurse's workload. Physical and non-physical workloads can increase work stress and may force nurses to suffer from psychological problems.

Job stress among the nurses can be reduced through the creation of a good and favorable work environment. If the nurses feel that their physical and non-physical environments are good and helpful, such situations will motivate them to manage job stress properly. The feeling of more secure at the workplace can also be developed through a good and favorable work environment. The nurses found it easier to develop harmonious relationships either with their superiors, coworkers, or subordinates and such a relationship helped the nurses to alleviate their job stress.

The capability of nurses in managing job stress and the supporting capacity of the work environment could also reduce the job stress. When nurses find that their job stress is low, it may enable them to finish their tasks or to develop a good work relationship with other medical workers and other staff. At least, it helps the nurses to work more effectively because they can use work tools and take actions to improve their performance.

The increase in workload could decrease nurse performance. Excessive workload could degrade nurse performance to a suboptimal level. Psychological anxiety, mental distraction, and fatigue (during the night shift) are what nurses may suffer as the consequences of high workload, which can force nurse performance to decline.

Meanwhile, to further improve the service performance of nurses in carrying out health care services, efforts are needed to improve the quality of competencies, work relationships and learning processes throughout the professional life. Pujiyanto, Suprihati, Nursalam, \& Ediyati (2017) state that improving the performance of care services is more effective by improving the quality of nursing work life. Furthermore, the scope of the nurse's work is to involve interaction with other professions. This requires attitudes and behaviors of quality work life to improve nursing work services. The quality of nursing work life must be improved by encouraging the learning process in order to increase understanding in professional work.

The results of the present study need to suggest the application of the healthy work environment standard and the health work environment of nurses (Paguio \& Yu, 2020). The application of these standards can increase work satisfaction and intention. This will also ensure an increase in nurse performance, employment status, and professional nurse (Ulrich et al., 2019).

This research was conducted to carry out the methodology objectivity in the scientific framework. However, several recognized weaknesses were found in the implementation. They were (i) the use of questionnaires still contains risks because sometimes, the respondents gave answers that do not describe their actual conditions; (ii) the research sample only involved the nurses working at Puskesmas in Tumpang District. The findings will be completer and more comprehensive if it involves the perception of the nurse colleagues, such as the supervisors or doctors; (iii) this research may require the formulation of a greater number of variables, in addition to workload, work environment, work stress and nurse performance.

\section{CONCLUSION AND SUGGESTION}

The average scores of workloads, work environment, work stress, and nurses' performance show values of 3.56, 3.95, 2.52, and 4.04, respectively. Overall, nurses worked in a pleasant work environment and successfully managed work stresses themselves even though they dealt with a high workload situation.

The condition of the work environment determines the performance of nurses in carrying out their duties. A good work environment encourages nurses to be more motivated to improve their performance. Besides, a good work environment can ensure nurses to feel more secure at the workplace. When working conditions are very comfortable and adequate, nurses feel facilitated to create more meaningful relationships with their supervisors, coworkers, or subordinates. Such feelings are very helpful for nurses to improve their performance. 
Furthermore, this is a matter of low workload associated with low job stress. This situation is supposed to be supportive of the improvement of nurse performance. Moreover, the improvement of nurse performance can be obtained from the creation of a good and supportive work environment where the job stress of the nurses is usually low in such an environment.

\section{REFERENCES}

Aiken, L. H., Sloane, D. M., Ball, J., Bruyneel, L., Rafferty, A. M., \& Griffiths, P. (2018). Patient satisfaction with hospital care and nurses in England: An observational study. BMJ Open, 8(1), 1-8. https://doi.org/10.1136/bmjopen2017-019189

Ambarwati, D., \& Lataruva, E. (2014). Pengaruh Beban Kerja Terhadap Stres Perawat Igd Dengan Dukungan Sosial Sebagai Variabel Moderating (Studi Pada RSUP Dr. Kariadi Semarang). Undergraduate thesis, Fakultas Ekonomika dan Bisnis. Universitas Diponegoro, Semarang. Retrieved from http://eprints.undip.ac.id/43376/1/01 AMBARW ATI.pdf

Difayoga, R., \& Yuniawan, A. (2015). Pengaruh Stres Kerja, Kepuasan Kerja, Dan Lingkungan Kerja Terhadap Kinerja Perawat. Diponegoro Journal of Management, 4(1), 1-10. Retrieved from s1.undip.ac.id/index.php/dbr

Hannani, A. (2016). Effect of Workload, Satisfaction and Facilities on The Perfomance of Nurse In UIT Hospital Makassar. Jurnal Mirai Management, 1(2), 516-526. Retrieved from https://journal.stieamkop.ac.id/index.php/mirai/ article/download/29/31

Hayes, B., Douglas, C., \& Bonner, A. (2015). Work environment, job satisfaction, stress and burnout among haemodialysis nurses. Journal of Nursing Management, 23(5), 588-598. https://doi.org/10.1111/jonm.12184

Indriyani, A. (2009). Pengaruh Konflik Peran Ganda Dan Stress Kerja Terhadap Perawat Wanita Rumah Sakit. Masters thesis, Diponegoro University. Retrieved from http://eprints.undip.ac.id/63337/

Laurant, M., van der Biezen, M., Wijers, N., Watananirun, K., Kontopantelis, E., \& van Vught, A. J. A. H. (2018). Nurses as substitutes for doctors in primary care. Cochrane Database of Systematic Reviews. John Wiley and Sons
Ltd.

https://doi.org/10.1002/14651858.CD001271.p ub3

Mangkunegara, A. A. A. P. (2012). Evaluasi kinerja SDM. Bandung: Refika Aditama. Retrieved from https://books.google.co.id/books?id=VBOg9va3 $\underline{8 \mathrm{icC}}$

Nieuwenhuijsen, K., Bruinvels, D., \& Frings-Dresen, M. (2010). Psychosocial work environment and stress-related disorders, a systematic review. Occupational Medicine (Oxford, England). https://doi.org/10.1093/occmed/kqq081

Nitisemito, A. S. (1982). Manajemen personalia: (Manajemen sumber daya manusia). Jakarta: Ghalia Indonesia. Retrieved from https://books.google.co.id/books?id=YBltnQEAC AA]

Paguio, J. T., \& Yu, D. S. F. (2020). A mixed methods study to evaluate the effects of a teamwork enhancement and quality improvement initiative on nurses' work environment. Journal of Advanced Nursing, 76(2), 664-675. https://doi.org/10.1111/jan.14270

Pujiyanto, T. I., Suprihati, S., Nursalam, N., \& Ediyati, A. (2017). Improving Nursing Work Services through Development Model of Quality of Nursing Work Life. Jurnal Ners, 12(2), 212218. https://doi.org/10.20473/jn.v12i2.6294

Rivai, V. (2009). Manajemen sumber daya manusia untuk perusahaan: dari teori ke praktik. Jakarta: Rajawali Pers. Retrieved from https://books.google.co.id/books?id=Rb7qZwEA CAA]

Rizki, M., Hamid, D., \& Mayowan, Y. (2016). Pengaruh Lingkungan Kerja Terhadap Stres Kerja Karyawan (Studi Pada Karyawan PT PLN (Persero) Distribusi Jawa Timur Area Pelayanan Malang). Jurnal Administrasi Bisnis (JAB)|Vol, 41(1), 9-15. Retrieved from http://administrasibisnis.studentjournal.ub.ac.id index.php/jab/article/view/1626/2010

Robbins, S. P., \& Judge, T. A. (2017). Organizational Behavior (17th ed.). Pearson. Retrieved from https://books.google.co.id/books?id=UKy1jgEA CAAJ

Shabbir, B., \& Naqvi, R. (2017). Impact of Workload and Job Complexity on Employee Job Performance with the Moderating Role of Social Support and Mediating Role of Job Stress: A Study of Travel agencies in Rawalpindi, 
Islamabad and AJK. Journal of Accounting \& Marketing, 06(01), 1-7. https://doi.org/10.4172/2168-9601.1000214

Shea, T., Pettit, T., \& De Cieri, H. (2011). Work Environment: The Impact of The Physical Woek Environment on Psychological Health, A Snapshot Review. Melbourne, Australia. Retrieved from http://research.iscrr.com.au/ data/assets/pdf file/0007/297763/Work-environment-stressimpact-on-psychological-health.pdf

Tuthill, N. (2009). Professional Nursing Concepts. AORN Journal, 90(4), 603-604. https://doi.org/10.1016/j.aorn.2009.09.016

Ulrich, B., Barden, C., Cassidy, L., \& Varn-Davis, N. (2019). Critical Care Nurse Work Environments 2018: Findings and implications. Critical Care Nurse, $39(2)$, 67-84.

\section{https://doi.org/10.4037/CCN2019605}

Van Den Hombergh, P., Künzi, B., Elwyn, G., Van Doremalen, J., Akkermans, R., Grol, R., \& Wensing, M. (2009). High workload and job stress are associated with lower practice performance in general practice: an observational study in 239 general practices in the Netherlands. BMC Health Services Research, 9, 1-8. https://doi.org/10.1186/1472-6963-9$\underline{118}$

Wollah, M. O., Rompas, S., \& Kallo, V. (2017). Hubungan Antara Stres Kerja Perawat dengan Kinerja Perawat di Instalasi Gawat Darurat dan Intensive Care Unit RSU Pancaran Kasih GMIM Manado. Jurnal Keperawatan, 5(2), 1-7. Retrieved from https://ejournal.unsrat.ac.id/index.php/jkp/articl e/view/17874/17395 
Appendix. Normality, Multicollinearity, and Heterogeneity Test

Normality test is aimed to examine whether regression model, or path model, and disturbance variable, or residual, have normal distribution. In case of Kolmogorov-Smirnov Test, if probability level is greater than 0.05 , then the assumption of normality is fulfilled.

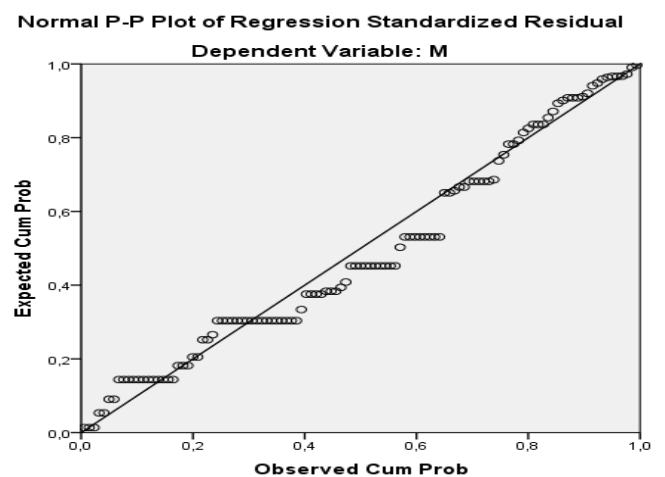

Results of Normality Test with Regression Residual

\begin{tabular}{ccc} 
Structural Equation & $\begin{array}{c}\text { Kolmogorov- } \\
\text { Smirnov } \mathrm{Z}\end{array}$ & $\mathrm{P}$ value \\
$\mathrm{X} 1, \mathrm{X} 2 \rightarrow \mathrm{M}$ & 1.222 & 0.101 \\
$\mathrm{X} 1, \mathrm{X} 2$ and $\mathrm{M} \rightarrow \mathrm{Y}$ & 1.059 & 0.212 \\
\hline
\end{tabular}

Note: $\mathrm{X} 1=$ Workload, $\mathrm{X} 2=$ Work Environment, $\mathrm{M}=$ Job Stress, $Y=$ Nurse Performance

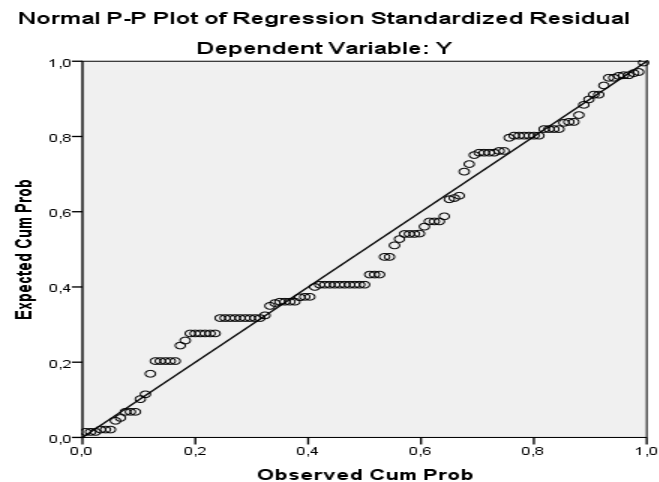

Graphics of Normal Probability Plot

Multicollinearity test was conducted to ensure whether there was correlation among independent variables in regression model. It is presented that independent variables of this research have Variance Inflation Factor of smaller than 10 . It can be said that there was no multicollinearity symptom in the correlation among independent variables.

\begin{tabular}{|l|l|c|c|}
\hline \multicolumn{4}{|c|}{ Coefficients $^{\mathbf{a}}$} \\
\hline \multicolumn{2}{|l|}{ Model } & \multicolumn{2}{|c|}{ Collinearity Statistics } \\
\cline { 3 - 4 } \multicolumn{2}{|l|}{} & Tolerance & VIF \\
\hline \multirow{2}{*}{1} & $\mathrm{X} 1$ & .539 & 1.855 \\
\cline { 2 - 4 } & $\mathrm{X} 2$ & .539 & 1.855 \\
\hline \multicolumn{2}{|l|}{ a. Dependent Variable: M } \\
\hline
\end{tabular}

\begin{tabular}{|l|l|c|c|}
\hline \multicolumn{4}{|c|}{ Coefficients $^{\mathbf{a}}$} \\
\hline \multirow{2}{*}{ Model } & \multicolumn{2}{|c|}{ Collinearity Statistics } \\
\cline { 3 - 4 } \multicolumn{2}{|l|}{} & Tolerance & VIF \\
\hline \multirow{3}{*}{1} & $\mathrm{X} 1$ & .456 & 2.191 \\
\cline { 2 - 4 } & $\mathrm{X} 2$ & .473 & 2.116 \\
\cline { 2 - 4 } & $\mathrm{M}$ & .500 & 1.999 \\
\hline \multicolumn{2}{|l|}{ a. Dependent Variable: $\mathrm{Y}$} \\
\hline
\end{tabular}

Heteroscedasticity test was carried out to see whether there was variance dissimilarity between one observed residual and another. Scatter plot graphic above shows that the dots are scattered randomly or dispersed orderly either over or beneath point 0 at Axis $Y$. Based on this depiction, it can be said that heteroscedasticity did not exist in regression model.
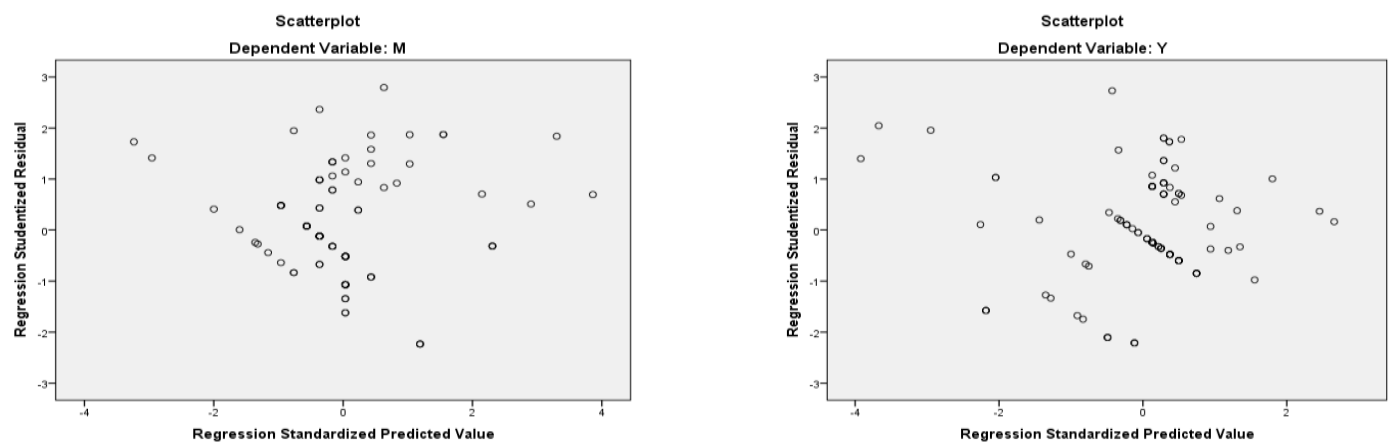

Scatter Plot 